\title{
Risk-Taking Competence of Intrapreneurs and Social Sustainability in Nigerian Oil and Gas Industry: An Operations Management Challenge
}

\author{
Olu-Daniels Sunday Olugbenga PhD \\ Spring Tech Investment, Port Harcourt, Nigeria. \\ sunny_oludaniels@yahoo.com \\ Ndu, Eugene Chigozie, $\mathrm{PhD}$ \\ Department of Hospitality Management and Tourism, Faculty of Management Sciences, University of Port \\ Harcourt, Nigeria. \\ eugene.ndu@uniport.edu.ng
}

\begin{abstract}
This study sought to establish the relationship between risk-taking competence of intrapreneurs and social sustainability. Social sustainability which is one of the dimensions of organisational sustainability was measured by human capacity development and community service; while risk-taking competence stood as the sole dimension of intrapreneurial competence. Two research hypotheses guided the study; while data were generated from a sample of 242 managers drawn from 19 upstream sector oil and gas companies in the South South region of Nigeria. Data were analyzed using the mean and standard deviation techniques; as well as the structural equation modeling techniques. It was found that there is significant and direct relationship between risk-taking competence and human capacity development; but no significant relationship exists between risk-taking competence and community service. Hence, the study concluded that risk-taking competence is a good antecedent of human capacity development; but has no significant predictive power on community service.

Keywords: Community Service, Human Capacity Development, Intrapreneurial competence and organisational Sustainability.

DOI: $10.7176 / \mathrm{EJBM} / 12-10-07$

Publication date: April $30^{\text {th }} 2020$

Introduction

Today, while the various needs and organisational objectives are worth craving and are essential to the organisation's survival, issues of climate change, globalization, demographic change and social inequality have significantly challenged the traditional form of doing business which was focused primarily on shareholder value, and there are ethical issues also which organisations must now contend with (Wales, 2013). Social sustainability has become a critical element of management discuss given the nexus that has dictated the organisations' operating environment and the larger society. Social sustainability which refers to the proper management of the impact of organisational operations on the social systems, requires that the anticipations of the various social groups of the organisation are considered and met. The challenge faced by organisations is no longer only limited to the demand for returns, but also ensuring that its operations do not have negative impact on the environment and the host communities. Achieving sustainability demands that the individual workers in the organisation, and the managers develop the right culture to build this kind of organization (Cusack, 2007). This situation has thus imposed the need for a continued search for ways of enhancing sustainability; especially, social sustainability.
\end{abstract}

The upstream sector companies of the Nigerian oil and gas industry, in bids to improve on the subsisting issues, have attempted modes such as institution of Global Memorandum of Understanding (GMoU) with communities in their areas of operations, creation of Cluster Developments Boards and aggressive staff development. These approaches have, regrettably, not yielded the desired results (Ene, 2015; Otiotio, 2016; Weli, 2017). It would be interesting therefore, to evaluate how the risk-taking competence of intrapreneurs influences the social sustainability structure of organisations in terms of the Nigerian environment, with reference to companies in the upstream sector of the oil and gas industry. In the intrapreneurship and corporate entrepreneurship literature, risk-taking competence involves the possession of the ability and skills for taking bold actions by venturing into the unfamiliar, borrowing heavily, and/or investing substantial resources to ventures in unknown environments (Rauch, Wiklund, Lumpkin \& Frese, 2009). Precisely, studies on the nexus between risk-taking competence of intrapreneurs and sustainability are rather sparse. Moreover, majority of these studies as found in literature are principally on foreign settings that bear no sameness with the Nigerian society and its business environment. This study therefore, was undertaken to close these gaps. 
Over time, the oil and gas industry in Nigeria has witnessed agitations and facility attacks by the local communities. These have tended to paralyze the industry through drastic reductions in the throughput proficiencies of the organisations, thus jeopardizing sustainability of the businesses in this industry. As proposed by Ene (2015) and corroborated by Otiotio (2016), the hostilities being experienced in the production fields have become endemic that fears have been experienced on how much longer the producing organisations can hold, if the situation remains unchanged. Facility attacks average about 75 occurrences per annum and it tends upward in trend (Ene, 2015; Akpata, 2014). In spite of the efforts by these oil and gas companies to reach out to the communities with respect to community development projects, agitations by the host communities have also continued unfettered. One of such companies had laid claims to investing more than N400 billion within a period of 10 years in such projects (Weli, 2017). But the agitations, with threats of shutdowns, have not abated; indicating a serious operations management challenge to these oil and gas companies. Given these challenges, it is expedient that the sustainability of organisations be investigated with particular emphasis on the social sustainability context (measured by "Human Capacity Development - HCD" and "Community Service") as predicted by the risk-taking competence of these oil and gas companies. Thus, this work explored the relationship between risk-taking competence and social sustainability as shown in the conceptual model of figure 1.

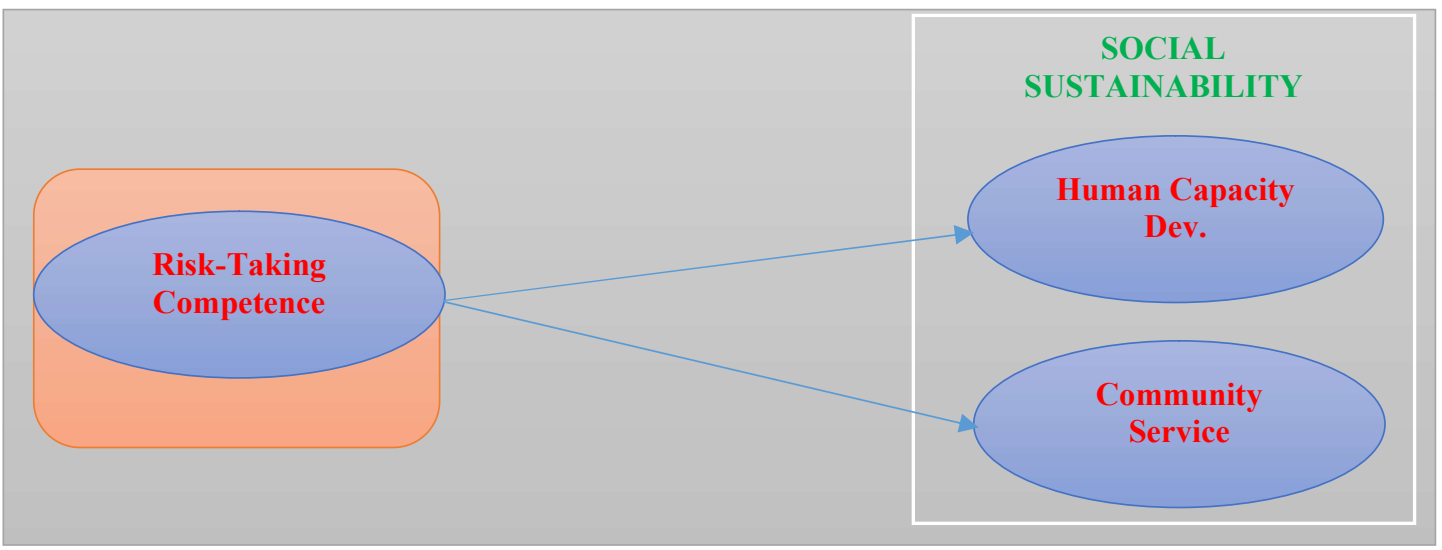

Figure 1: Conceptual Model of the Relationship between Risk-Taking Competence and Social Sustainability.

Source: Researchers' Conceptualization, 2019; based on dimension and measures adapted from Miller (1983); Rauch, Wiklund, Lumpkin, and Frese (2009); de Jong, Parker, Wennekers, and Wu (2011); Maletič, Maletič, and Gomišček (2012)

The study objectives were to:

i. Establish the link between risk-taking competence and Human capacity development (HCD) measure of social sustainability.

ii. Identify the relationship between risk-taking competence and community service measure of social sustainability.

From the stated objectives, two hypotheses were formulated and tested. They are:

$\boldsymbol{H}_{0}: \mathbf{1}$ There is no significant link between risk-taking competence of intrapreneurs and HCD measure of social sustainability.

$\boldsymbol{H}_{0}: 2$ There is no significant relationship between risk-taking competence of intrapreneurs and community service measure of social sustainability.

It is expected that this study will offer a basis for analysing the relationship existing between the organisation and its employees; as it is hoped that the employee will add to the organisation's sustainability through risktaking. This study is equally expected to add to the knowledge base on sustainability; by stimulating further research interests on the subject matter. In terms of the content scope, the study was limited to risk-taking competence as a dimension of intrapreneurial competence; HCD and community service as measures of social sustainability. Geographically, the study focused on managers in the upstream sector of the oil and gas industry in the South-South region of Nigeria.

\section{Literature/Theoretical Underpinning}

The literature review in this study was presented under the following sub-headings - conceptual clarifications, theoretical framework and empirical literature. 


\section{Conceptual Clarifications}

Risk-taking Competence: Since Cantillon (as cited in de Jong Parker, Wennekers \& Wu, 2011) defined an entrepreneur as one who bears the risk of profit or loss, risk-taking has been considered as an essential component of entrepreneurship (Antoncic \& Hisrich, 2003; Wennekers, Thurik, van Stel \& Noorderhaven, 2007). In the intrapreneurship and corporate entrepreneurship literature, risk-taking competence involves the possession of the ability and skills for taking bold actions by venturing into the unfamiliar, borrowing heavily, and/or investing substantial resources to ventures in unknown environments (Rauch, Wiklund, Lumpkin \& Frese, 2009). Ling, Simsek, Lubatkin and Veiga (2008) demonstrated that risk-taking by top management team members increases the odds of corporate entrepreneurship activities. Individual intrapreneurship definitions suggest that intrapreneurs engage in risky situations characterized by potential losses. Thus, Vesper (as cited in Hornaday, Tarpley Jr., \& Timmons, 1984) stressed that intrapreneurs would even act without their higher management's permission. While Stevenson and Jarillo (1990) stressed opportunity pursuit beyond currently controlled resources; just as Antoncic and Hisrich (2003) emphasized deviating from the status quo. In related literature, proactive behaviours have also been considered 'risky' as they change the individual's environment by selling controversial issues (Parker \& Collins, 2010). In summary, at the individual level, risk-taking is implicitly present in many of the related constructs that have been proposed. There has been an on-going debate on risktaking role in intrapreneurial venturing. There is the argument that entrepreneurs prefer moderate rather than high risks, and try to manage and reduce risks as much as possible. For instance, Pinchot (1987) emphasized that when a difficult task venture is selected, entrepreneurs try within their capability to lessen the risk. Nevertheless, as an intrapreneur pursues opportunities and consequently operates in uncertain environments, some risk-taking will be part of his/her behaviour by default. In this context, a meta-analytic review by Stewart \& Roth (2001) showed that entrepreneurs whose primary goal was venture growth (versus family income) were more disposed to take risks, suggesting that those who are more likely to deviate from the status quo should bear higher risks.

Social Sustainability: Social sustainability is the proper management of the organisational operations impact on the social systems. Social sustainability requires that the anticipations of the various social groups of the organisation are considered and met. Munck et al. as cited in Cella-De-Oliveira, (2013) assert that it integrates questions relating to human development: training; education; workplace safety; occupational health; and competence development; and equality: fair salaries and benefits; equal opportunities and absence of workplace discrimination, to ethical considerations: cultural values; human rights; intergeneration and intra-generation justice. To profit of its best from the employee demands that the most beneficial behaviours from the human resources is central and must be satisfied. Such serious areas as motivation, skills and loyalty of employees and business partners need to be given a prime importance. As proposed by Azapagic (as cited in Cella-De-Oliveira, 2013), social sustainability shields areas such as fair pay, equal opportunities, good health and safety conditions, gratification system, securing ideas for the enhancement of the Triple Bottom Line, competence development and training, career plans and ethical organizational behaviour. Accordingly, two measures of social sustainability highlighted by Munck et al.; Azapagic, as cited in Cella-De-Oliveira, (2013) will be used, these measures are human capital development and community service.

\section{Theoretical Framework}

The theoretical anchor of this work is the Resource Based View (RBV) theory which according to Jacquier (2010), integrates the capabilities and resources of an organisation to achieve sustainability. It describes the intrapreneurial part in stimulating organisational growth and its application to achieve encouraging organisational targets. According to Jacquier (2010), these resources and competences are crucial for the purposes of the organization's performance explanation and offering it competitive advantage. This is based on the principle that organizational capabilities and resources create organisational value. To leapfrog the industry standard, an organisation must create more value than its competitors. The idea of RBV is that firms are seen to comprise of both material and immaterial assets and abilities through which the success of their functional activities are determined.

\section{Empirical Literature \\ Risk-taking Competence and Human Capacity Development (HCD)}

Managerial competency has been identified as one of the most crucial criteria for achieving organizational sustainability (Veliu \& Manxhari, 2017). Managers are constantly under pressure to deliver and ensure that organizations achieve their predetermined objectives (Mirta, Alvaro \& Ramon, 2014; Veliu \& Manxhari, 2017). This reality has prompted Veliu and Manxhari (2017) to assert that in measuring organizational performance, it is better to focus more on human resources rather than material resources alone. Therefore, in the discourse of organizational sustainability, HCD should be given keen attention as its importance cannot be overemphasized (Becker 1993; Schultz 1993; Agarwala 2003; Lumpkin \& Dess, 2005; Sevrine \& Lila 2009; Marimuthu, 
Arokiasamy \& Ismail 2009; Odhon'g \& Omolo 2015; Veliu \& Manxhari, 2017) have agreed that human capital development gives an organization a competitive advantage over their competitors thereby improving organizational performance. In analysing the personality traits of an entrepreneur, recent studies have also confirmed that risk-takingg is a major trait of successful entrepreneurs (Boyd \& De Nicolo, 2014; Cress, 2006; Rauch \& Frese, 2007). Furthermore, a few studies have shown that the competence, willingness and attitude of managers and employees to risk- taking have a significant effect on business success. In a study titled 'the effect of entrepreneurial competencies on business performance: a case of Kenya's public transport industry' Kimeu (2017) established that risk-takingg and business performance are meaningfully correlated Similarly, Nieuwenhuizen and Kroon (2002) revealed a strong relationship between the willingness of employees to take risks and entrepreneurial business success; thus emphasizing the need for capacity development in employees. They suggest that risk awareness and caution is a veritable tool for achieving a higher profit level. These arguments necessitate the need for business organizations to improve the risk-taking ability of their employees with no exception to the Nigerian oil and gas industry. Building on these previous studies, the researcher hopes to investigate the relationship between risk-taking competence and HCD of the Nigerian oil and gas industry. Hence the formulation of hypothesis one which state thus:

$\boldsymbol{H}_{0}: 1$ There is no significant correlation between risk-taking competence of intrapreneurs and HCD measure of social sustainability.

Risk-taking Competence and Community Service

The perception of the society on the implications of operations and conducts of organizational activities on the generality of their communities is an emerging challenge on the sustainability of business enterprises. Those calling for social justice have been inevitably pitted against those advocating for unfettered managerial capitalism. Porter and Kramer (2011) noted this when they asserted that "The capitalist system is under siege. Companies are widely perceived to be prospering at the expense of the broader community". This notion places a strain on the sustainability of the organization. Cusack (2007) succinctly captured this when he stressed that sustainability issues can directly affect a company's success and the perceived value of the organization. Apparently, in today's information rich world, there is no hiding place for any organization treating sustainability issues with levity.

Organizations in the upstream sector of the Nigerian oil and gas industry, in bids to improve on the subsisting issues, have attempted modes such as institution of Global Memorandum of Understanding (GMoU) with communities in their areas of operations, creation of Cluster Development Boards and aggressive staff development. These approaches have, regrettably, not yielded the desired results (Ene, 2015; Otiotio, 2016; Weli, 2017). This is quite revealing as scholars like Ndubuisi and Asia (2007), Ayuba (2012), Anosike (2014), Egwuonwu (2014) have all noted that in spite of these efforts, conflict still abounds between host communities and oil companies. This repeated agitation has been seen as threat to the sustainability of the oil and gas industry in Nigeria Idemudia (2007) found that these strive were as a result of poor partnership effort form the oil merchants with their hosts. Scholars such as (Takon, 2014; Anosike, 2014; Egwuonwu, 2014; Ayuba, 2012; Ugochukwu, 2008) in their various studies also share in this view. Surprisingly, Onishi (2002) lamented that the needs of these communities are so numerous and cannot be satisfied by the ordinary concept of social responsibility. Frynas (2005) and Akpan (2006) lamented in this same direction stating that the commitment of the oil industry to community development is abysmal. These challenges therefore necessitate further inquiry to explore intrepreneurship strategies for combating the menace. In this light, the researcher hoped that risk-taking competence as dimension of intrepreneurship may be a good predictor of community service. Thus the formulation of hypothesis two which states that:

$\boldsymbol{H}_{0}: 2$ There is no significant correlation between risk-taking competence of intrapreneurs and community service measure of social sustainability.

\section{Methodology}

The cross-sectional survey method, a form of quasi-experimental design, was considered most appropriate for this study. The large and diverse nature of this study's population also supports the aptness of the cross-sectional survey design which is widely used in administrative and social sciences, partly due to the complex relationships existing among social variables. The population of the study consists of nineteen (19) oil and gas producing firms, operative in the upstream sector of the oil and gas industry in the South South region of Nigeria (DPR, 2015). These firms comprise the joint venture partners, and the other enterprises in possession of oil mining leases the government granted for the search of, win, work, carry away and dispose of petroleum. There are 623 managers in these firms, according to personnel records, and this formed the population frame. The sample representation of 242 was ascertained via the Krejcie and Morgan's table for sample size determination (as cited in Sekaran, 2008). The study sample was obtained by cluster sampling, with the respective nineteen firms 
representing a cluster. The respondents of every cluster were determined by proportional sampling and respondents were selected by simple random sampling. This was to ensure the inclusion of all the organisations in the sample and that every manager had an equal probability of being included in the sample.

Primary and secondary data were utilized in sourcing for data. The "questionnaire" was the fundamental tool for the collection of primary data; while secondary data was collected from the review of previous studies with respect to the subject matter. The questionnaire was adapted from a mix of validated instruments for measuring the various study variables (Maletič, M., Maletič, D., \& Gomišček, 2012; de Jong \& Wennekers, 2008; Worley, Fuqua, \& Hellman, 2009). It was personally administered, through the aid of resource persons. The criterion variable (social sustainability) comprised two measures; while the predictor variable is risk-taking. Researchers have identified various measures used in determining these variables as noted in the literature reviewed (See for example, Maletič, M., Maletič, D., \& Gomišček, 2012; de Jong \& Wennekers, 2008; de Jong, Parker, Wennekers, \& Wu, 2011; Worley, Fuqua, \& Hellman, 2009). To measure these variables, study elements were demanded to react to various statements on the measures adapted from previous authors as earlier discussed.

To confirm validity, the convergent and discriminant validities of the constructs was ascertained through a confirmatory factor analysis (CFA). Reliability of the instrument was ascertained through the composite reliability scores of the constructs which showed a minimum reliability coefficient of 0.898 ; exceeding the threshold mark of 0.6 for exploratory studies and 0.7 for confirmatory studies (Nunnally, 1978 \& 1979). Responses obtained were recorded on a four-point Likert scale instrument varying from "Strongly Disagree", based on the researcher's opinion (Score: 1 point) to "Strongly Agree" also of the researcher's opinion (Score: 4 points). Univariate data were analyzed with mean and standard deviation techniques; while bivariate analysis were performed using structural equation modeling (SEM) techniques which is a compendium of analysis involving factor analysis, hierarchical regression modeling and path analysis. These were aided by the statistical Package for the Social Sciences (SPSS) version 21. The confidence level for this study was set at $95 \%$, implying a 0.05 significance level. Pearson's product moment correlation technique was adopted to derive the correlation matrix showing the correlations among the studied variables (Boone \& Boone, 2012, Joshi et al., 2015; Norman, 2010). Since the sample size is relatively large, the assumptions of normality, linearity, homoscendasticity and absence of multicollinearity apply (Osborne, Jason \& Waters, 2002; Statistics Solutions, 2017). The underlying conventions for using the SEM analysis techniques was also complied with since the sample size is above 200 (Hair et al, 2010).

\section{Results/Findings}

Out of the 242 copies of the instrument administered, 226 copies (93.3\%) were retrieved. However, 9 copies of the retrieved questionnaire were found not usable; leaving only 217 copies $(89.6 \%)$ that were accurately filed for use in the analysis.

\section{Descriptive Analysis Result of Data on Risk-taking Competence}

\begin{tabular}{|l|r|r|r|r|r|}
\hline & \multicolumn{1}{|c|}{$\mathrm{N}$} & \multicolumn{1}{|c|}{ Minimum } & Maximum & \multicolumn{1}{|c|}{ Mean } & Std. Deviation \\
\hline Risk Taking Competence & 217 & 2.67 & 4.00 & 3.6682 & .35932 \\
Valid N (listwise) & 217 & & & & \\
\hline
\end{tabular}

Table 1: Descriptive Analysis Results of Risk-taking Competence

Source: Field Survey, 2018

Table 1 shows the descriptive analysis of data gathered on Risk-taking competence. The table revealed a minimum value of 2.67 and maximum value of 4.00. Furthermore, the result showed a mean $(M)$ of 3.66 and standard deviation $(S D)$ of 0.35 . According to Asawo (2009), the mean returns were classified as 1.0 to $2.0-$ low, 2.1 to 2.8 - moderate, 2.9 to 3.5 - high and above 3.5 - very high. This forms the bases for the univariate analyses. Thus based on this, the construct risk-taking competence returned a very high mean depicting that respondents considered it as possessing a very high scale in their perception. 


\begin{tabular}{|l|r|r|r|r|r|}
\hline & N & Minimum & Maximum & \multicolumn{1}{c|}{ Mean } & Std. Deviation \\
\hline risk taking competence1 & 217 & 1.00 & 4.00 & 3.5991 & .63143 \\
risk taking competence2 & 217 & 1.00 & 4.00 & 3.7143 & .60202 \\
risk taking competence3 & 217 & 2.00 & 4.00 & 3.6912 & .52842 \\
Valid N (listwise) & 217 & & & & \\
\hline
\end{tabular}

\section{Table 2: Descriptive Analysis Result for Data Items on Risk-taking Competence}

Source: Field Survey, 2018

Table 2 showed the descriptive result for each of the questionnaire items raised on risk-taking competence. The result revealed a minimum mean $(M)$ of 3.59 which means that all the items were adjudged to be very highly applicable.

\section{Descriptive Analysis of Data on Social Sustainability}

Social sustainability for the purpose of this study was a measured with HCD and Community service.

\begin{tabular}{|l|r|r|r|r|r|}
\hline & N & Minimum & Maximum & \multicolumn{1}{c|}{ Mean } & Std. Deviation \\
\hline Human Development & 217 & 1.50 & 4.00 & 3.7696 & .39075 \\
Valid N (listwise) & 217 & & & & \\
\hline
\end{tabular}

\section{Table 3: Descriptive Analysis Result for HCD}

Source: Field Survey, 2018

Table 3 showed the descriptive analysis result for HCD. The result showed a mean $(M)$ of 3.76 and standard deviation $(S D)$ of 0.39 . depicting that the construct was accepted by the respondents as very highly applicable for the study.

\begin{tabular}{|l|r|r|r|r|r|}
\hline & N & Minimum & Maximum & \multicolumn{1}{c|}{ Mean } & Std. Deviation \\
\hline Human Capacity Dev. 1 & 217 & 1.00 & 4.00 & 3.7281 & .54839 \\
Human Capacity Dev. 2 & 217 & 1.00 & 4.00 & 3.8111 & .49653 \\
Human Capacity Dev.3 & 217 & 1.00 & 4.00 & 3.7281 & .54839 \\
Human Capacity Dev. 4 & 217 & 1.00 & 4.00 & 3.8111 & .49653 \\
Valid N (listwise) & 217 & & & & \\
\hline
\end{tabular}

Table 4: Descriptive Analysis Result for the Indicators of HCD

Source: Field Survey, 2018

Table 4 showed the descriptive analysis result for the indicators of HCD. The table revealed a minimum mean $(M)$ of 3.72 indicating that all the items were accepted by the respondents as very highly applicable for the study.

\begin{tabular}{|l|r|r|r|r|r|}
\hline & $\mathrm{N}$ & Minimum & Maximum & \multicolumn{1}{l|}{ Mean } & Std. Deviation \\
\hline Community Service & 217 & 2.50 & 4.00 & 3.7419 & .35058 \\
Valid N (listwise) & 217 & & & & \\
\hline
\end{tabular}

Table 5: Descriptive Analysis Result for Community Service

Source: Field Survey, 2018

Table 5 showed the descriptive analysis result for community service which is the second sub-dimension of social sustainability. The result revealed a mean $(M)$ of 3.74 and standard deviation $(S D)$ of 0.35 implying that the construct was accepted by the respondents as very highly applicable for the study. 


\begin{tabular}{|l|r|r|r|r|r|}
\hline & N & Minimum & Maximum & Mean & Std. Deviation \\
\hline Community Service 1 & 217 & 2.00 & 4.00 & 3.7788 & .44816 \\
Community Service 2 & 217 & 2.00 & 4.00 & 3.7051 & .49593 \\
Community Service 3 & 217 & 2.00 & 4.00 & 3.7788 & .44816 \\
Community Service 4 & 217 & 2.00 & 4.00 & 3.7051 & .49593 \\
Valid N (listwise) & 217 & & & & \\
\hline
\end{tabular}

Table 6: Descriptive Analysis of the Indicators of Community Service

Source: Field Survey, 2018

Table 6 showed the descriptive analysis result of the indicators of community service, which is the second subdimension of social sustainability. The results showed a minimum mean $(M)$ value of 3.70 meaning that all the items were adjudged to be very highly applicable.

\begin{tabular}{|c|c|c|c|c|c|c|c|}
\hline Constructs & Items & Mean & S.D & $\begin{array}{l}\text { Factor } \\
\text { Loadings }\end{array}$ & C.R & AVE & $\begin{array}{l}\text { Sq. } \\
\text { Root } \\
\text { of } \\
\text { AVEs }\end{array}$ \\
\hline \multicolumn{8}{|l|}{$\begin{array}{l}\text { Risk-takingg } \\
\text { Competence }\end{array}$} \\
\hline & $\begin{array}{l}\text { We have employees who take risks in executing their } \\
\text { jobs. }\end{array}$ & 3.5991 & .63143 & .906 & .926 & .807 & .898 \\
\hline & $\begin{array}{l}\text { When large interests are at stake, we have employees } \\
\text { who go for the 'big win' even when things could go } \\
\text { seriously wrong. }\end{array}$ & 3.7143 & .60202 & .882 & & & \\
\hline & $\begin{array}{l}\text { We have employees who first act and then ask for } \\
\text { approval, even if he/she knows that would annoy } \\
\text { other people. }\end{array}$ & 3.6912 & .52842 & .904 & & & \\
\hline \multicolumn{8}{|l|}{$\begin{array}{l}\text { Human Capacity } \\
\text { Dev. }\end{array}$} \\
\hline & $\begin{array}{l}\text { Security and employees' well-being is a priority of } \\
\text { our organization }\end{array}$ & 3.7281 & .54839 & .914 & .898 & .691 & .831 \\
\hline & $\begin{array}{l}\text { Our employees are encouraged to continuously } \\
\text { develop their talents and capacities }\end{array}$ & 3.8111 & .49653 & .880 & & & \\
\hline & $\begin{array}{l}\text { Employees are loyal to our organization (low } \\
\text { turnover and absenteeism rate) }\end{array}$ & 3.7281 & .54839 & .691 & & & \\
\hline & $\begin{array}{l}\text { Workers are valued and their work is organized to } \\
\text { conserve and enhance their efficiency and creativity }\end{array}$ & 3.8111 & .49653 & .822 & & & \\
\hline \multicolumn{8}{|l|}{$\begin{array}{l}\text { Community } \\
\text { Serv. }\end{array}$} \\
\hline & $\begin{array}{l}\text { We have developed a strategy for corporate social } \\
\text { responsibility. }\end{array}$ & 3.7788 & .44816 & .860 & .939 & .793 & .891 \\
\hline & Our organization is involved in the local community. & 3.7051 & .49593 & .936 & & & \\
\hline & $\begin{array}{l}\text { Our organisation is responsive to the community } \\
\text { needs. }\end{array}$ & 3.7788 & .44816 & .853 & & & \\
\hline & $\begin{array}{l}\text { Our community engagement system is anticipatory } \\
\text { and proactive. }\end{array}$ & 3.7051 & .49593 & .909 & & & \\
\hline
\end{tabular}

Table 7: Assessment of the Constructs

Source: IBM SPSS Analysis Result, 2018

Table 7 shows the assessment of the constructs based on CFA, which substantiated both the convergent and discriminant validity of the constructs. Specifically, the construct comprises 3 questionnaire items. First and foremost, the factor loadings of all the indicators were estimated; with the result showing a minimum loading of .691 which exceeded the threshold of 0.6 (Bagozzi, Yi \& Philip, 1991) and were significant at $p<0.000$; thus establishing the convergent validity of the constructs., The composite reliability (CR) scores of the constructs were .926 for risk-taking, .898 for HCD and .939 for community service; indicating high level of reliability. The Average Variance Extracted (AVE) values .807, .691 and 793 which are above the 0.50 benchmark (Akter, Wamba \& D' Ambra, 2016; Bagozzi \& Yi, 2012), also indicate satisfactory result. 


\begin{tabular}{lccccc}
\hline Constructs & Mean & S.D & Pro. Comp. & $\begin{array}{l}\text { Human } \\
\text { Cap. Dev. }\end{array}$ & Comm. Serv. \\
\hline Risk-taking Competence & 3.668 & .3593 & .926 & \\
Human Cap. Dev. & 3.742 & .3506 & .879 & .898 & .939 \\
Comm. Service & 3.714 & .4155 & .293 & .341 & .939 \\
\hline
\end{tabular}

Table 8: Correlation Matrix of the Study Constructs

* The square root of the AVEs on the diagonal

Source: IBM SPSS Analysis Result, 2018

The table 8 showed the correlation matrix of the constructs together with the square roots of the AVEs shown on the diagonal; as well as the mean and standard deviation. As previously proposed in the methodology, Pearson's product moment correlation technique was used in deriving the correlation coefficients. From the correlations the result revealed that each of the constructs explained itself better than it explained other constructs since they showed a stronger correlation coefficient with their own construct than that of others. Furthermore, the study revealed that the square roots of the AVEs indicate that the constructs do not share similar items but are rather distinct from each. This is evidenced from the fact that the square roots of the AVEs were greater than the correlation values; thus confirming discriminant validity.

Result for Hypothesis One

\begin{tabular}{|l|r|r|r|r|r|}
\hline Model & \multicolumn{1}{|c|}{$\mathrm{R}$} & R Square & $\begin{array}{c}\text { Adjusted R } \\
\text { Square }\end{array}$ & $\begin{array}{c}\text { Std. Error of the } \\
\text { Estimate }\end{array}$ & Durbin-Watson \\
\hline 1 & $.879^{\mathrm{a}}$ & .773 & .772 & .192 & 1.733 \\
\hline
\end{tabular}

Table 9: Model Summary

a. Predictors: (Constant), Risk-takingg Competence

b. Dependent Variable: Human Capital Development

\begin{tabular}{|c|c|c|c|c|c|}
\hline \multirow[t]{2}{*}{ Model } & \multicolumn{2}{|c|}{ Unstandardized Coefficients } & \multirow{2}{*}{$\begin{array}{c}\begin{array}{c}\text { Standardized } \\
\text { Coefficients }\end{array} \\
\text { Beta }\end{array}$} & \multirow[t]{2}{*}{$\mathrm{t}$} & \multirow[t]{2}{*}{ Sig. } \\
\hline & $\mathrm{B}$ & Std. Error & & & \\
\hline (Constant) & 2.301 & .057 & & 40.505 & .000 \\
\hline Risk-takingg Competence & .440 & .016 & .879 & 27.060 & .000 \\
\hline
\end{tabular}

\section{Table 10: Coefficients}

a. Dependent Variable: HCD

Source: IBM SPSS Analysis Result, 2018

Tables 9 and 10 showed the result for hypothesis one. They revealed a significant $(\mathrm{P}$-value of $0.000<0.05)$ and high $(\beta=0.879)$ direct relationship between risk-taking competence and HCD. The adjusted $\mathrm{R}^{2}$ value of 0.772 shown in the model summary indicates that risk-taking competence is a strong predictor of HCD as it boasts of $77.2 \%$ predictive ability, leaving $23.8 \%$ to other factors not accommodated in the model.

\section{Result for Hypothesis Two}

Table 11: Model Summary

\begin{tabular}{|l|r|r|r|r|r|}
\hline Model & \multicolumn{1}{|c|}{$\mathrm{R}$} & R Square & $\begin{array}{c}\text { Adjusted R } \\
\text { Square }\end{array}$ & $\begin{array}{c}\text { Std. Error of the } \\
\text { Estimate }\end{array}$ & Durbin-Watson \\
\hline 1 & $.293^{\mathrm{a}}$ & .086 & .084 & .577 & 1.733 \\
\hline
\end{tabular}

a. Predictors: (Constant), Risk-takingg Competence

b. Dependent Variable: Community Service 


\begin{tabular}{|c|c|c|c|c|c|}
\hline \multirow[t]{2}{*}{ Model } & \multicolumn{2}{|c|}{ Unstandardized Coefficients } & Standardized & \multirow[t]{2}{*}{$\mathrm{t}$} & \multirow[t]{2}{*}{ Sig. } \\
\hline & $\mathrm{B}$ & Std. Error & Beta & & \\
\hline (Constant) & -1.097 & .170 & & -6.434 & .000 \\
\hline Risk-takingg Competence & 1.320 & .049 & .293 & 27.060 & .128 \\
\hline
\end{tabular}

Table 12: Coefficients

a. Dependent Variable: Community Service

Source: IBM SPSS Analysis Result, 2018

Tables 11 and 12 showed the result for hypothesis two. They revealed no significant $(\mathrm{P}$-value of $0.128>0.05)$ relationship between risk-taking competence and community service. The adjusted $\mathrm{R}^{2}$ value of 0.084 shown in the model summary indicates that risk-taking competence is not a good antecedent of community service. Thus the adjusted $\mathrm{R}^{2}$ value may have been per chance.

\section{Discussion}

The result for hypothesis one indicated that there is a significant correlation between the two variables as the $p$ value which is 0.000 is less than the 0.05 level of significance. Support for this was found in the works of Nieuwenhuizen and Kroon (2002) which revealed a strong relationship between the willingness of employees to take risks and entrepreneurial business success; thus emphasizing the need for capacity development in employees. Also supportive is the work of Veliu and Manxhari (2017) in which they used their study to assert that in measuring organizational performance, it is better to focus more on human resources rather than material resources alone. Other supportive studies include Becker (1993), Schultz (1993), Agarwala (2003), Lumpkin and Dess (2005), Severine and Lila (2009), Marimuthu et al (2009), Odhon'g and Omolo (2015), Veliu and Manxhari (2017).

This result was anticipated because, it is quite risky to train and develop employees as one does not know what decisions they might make after training; such as, leaving the organization for another one in search of greener pastures or not. In which case, the investment made would have been lost. Thus, only risk-taking intrapreneurs will dare to take such a risk. This may be premised on the fact that with risk-taking competence of the intrapreneurs it may be possible to analyse the turnover expectations based on trends and thus be able to effectively advise on the HCD steps and strategies to adopt for optimum results. Moreover, with risk-taking competence effectively harnessed, there may result a company-wide awareness of the subsistence and the possibilities it offers, thus enhancing the interests of the workforce; and ultimately leading to improvements in the HCD of the organisation. This finding also agrees with the RBV theory which is anchored on sustainability and emphasizes the need for HCD as a major way of fostering and engendering sustainability.

The result for hypothesis two indicated that there is no significant correlation between the two variables as the $\mathrm{p}$ value which is 0.128 is greater than the 0.05 level of significance. Support for this finding was found in the works of Onishi (2002) who used his work to demonstrate that the needs of oil communities are so numerous that they cannot be satisfied by the ordinary concept of social responsibility. Similarly, Idemudia (2007) found that the strivings between oil companies and their hosts are as a result of poor partnership effort in the area of community development. Other supportive studies include Ayuba (2012), Anosike (2014), Egwuonwu (2014), Takon, (2014), Ugochukwu (2008). Since the result indicated no significant relationship between the two variables in this hypothesis, the correlation value $(0.293)$ which is very low could only be best explained as spurious and of non-effect.

This result was not surprising because community service cum development issues (especially, in the study area) have become monsters whose taming has become a daunting challenge to the leadership and operations management of oil companies. This result of no significant relationship between the two variables may have been as a result of the subsisting situation in the communities where many attempts at reaching a truce and causing improvements in the relationships with the oil and gas companies have proved unsuccessful. It is also possible that this result was obtained as a result of the suspicion and mistrust that has trailed the relationship between oil companies and their host communities; thus, making any genuine community service effort of non effect. Although community services have remained a source of concern to both government and corporate entities, the search for solutions have continued to be unnerving. This has been demonstrated in the finding of insignificant relationship between the risk-taking competence of intrapreneurs and community service measure of social sustainability in this study. 


\section{Implication to Research and Practice}

The findings of this study indicate that whereas risk-taking competence of intrapreneurs significantly influences the human capacity development measure of social susstainabiliy, it does not relate significantly with the community service measure of social sustainability. These have far-reaching implications for both research and practice. In terms of research, the findings imply that not all aspects of social sustainability can be predicted by risk-taking. Such that researchers wishing to establish the relationship between risk-taking competence of intrapreneurs and social sustainability must do so with respect to specific measures of social sustainability so as to avoid misleading or unreliable outcomes. In terms of practice, the findings have shown that managers and owners of organizations desiring to achieve social sustainability especially in the Nigerian oil and gas industry should endeavour to create atmosphere that encourages the risk-taking competence of intrapreneurs in their organizations. However, they should be mindful of the fact that not all aspects of social sustainability can be significantly influenced by risk-taking competence. They should also note that risk-taking behaviour accommodates mistakes as aspect of the learning process. Hence, organizations wishing to encourage these behaviors among their members should make adequate provision for mistakes. Rather than punish such mistakes or deviations from the norms, they should sift out the excesses while guiding and encouraging the process.

\section{Conclusion}

The analysis on the first hypothesis signified that there is a significant and strong direct relationship between the two variables. Based on this it was concluded that risk-taking competence is a strong predictor of HCD submeasure of social sustainability. Furthermore, the study showed that risk-taking competence can be used to predict HCD to the tune of about $77 \%$; leaving the remaining $23 \%$ to other factors not captured in the model such as were mentioned earlier. Hence, for there to be improvement in the predictive power of risk-taking competence on HCD, there is need for effective control of these environmental factors. The result of the analysis on the second hypothesis indicated that there is no significant relationship between the two variables. Consequently, it was concluded that risk-taking competence of oil and gas companies' intrapreneurs is not a good antecedent of the community service measure of social sustainability. The negligible and insignificant predictive power of risk-taking competence on community service $(8.6 \%)$ indicates that for there to be improvement in the predictive power of risk-taking competence on community service, there is need for effective control of several other exogenous factors; thereby calling for effective operational and leadership abilities.

\section{Future Research}

Based on the identified limitations, the following suggestions are made for further studies.

1. This study could be replicated using the midstream and downstream sectors to ascertain if the findings differed significantly from those in this study. This could be approached also from the standpoint of a comparative study based on the two streams.

2. For the aim of inclusiveness, future researchers are advised to include the two sectors in their sample and as many companies as possible including registered and unregistered ones. Economic and environmental sustainability might also be incorporated into the criterion variable for completeness. This will help guarantee robustness of the study, validity, reliability and generalizability.

3. Future studies could also adopt other research designs such as longitudinal surveys. This will help to aggregate the dynamics of changing times and situational factors.

4. The study could be conducted in other industries not related to the oil and gas industry.

\section{References}

Agarwala, T. (2003). Innovative human resource practices and organizational commitment: An empirical investigation. International Journal of Human Resource Management, 14(2), 175-197.

Akpan, W. (2006). Between responsibility and rhetoric: Some consequences of CSR practices in Nigeria' soil province. Development Southern Africa, 23(2), 223-240.

Akpata, U. (2014). Review of the Nigeria oil and gas industry 2014. Retrieved from http://www.pwc.com/ng/en/assets/pdf/review-of-nigeria-oil-and-gas-industry.pdf

Akter, S., Wamba, S. F., \& D’Ambra, J. (2016). Enabling a transformative service system by modelling quality dynamics. International Journal of Production Economics. Retrieved from http://dx.doi.org/10.1016/j.ijpe.2016.08.025

Anosike, C. A. (2014). Sustainability Efforts of One Oil Company in Niger Delta of Nigeria. Walden Dissertations and Doctoral Studies Collection. Retrieved from: http://scholarworks.waldenu.edu/dissertations

Antoncic, B. and Hisrich, R. D. (2003). Clarifying the intrapreneurship concept. Journal of Small Business and Enterprise Development; 10(1), 7-24. 
Asawo, N.P. (2009). Unwavering hope and workers' commitment in the Nigerian manufacturing industry: A study in workplace spirituality. Retrieved from: https://www.researchgate.net/publication/265707476

Ayuba, K. A. (2012). Environmental Impacts of Oil Exploration and Exploitation in the Niger Delta of Nigeria. Global Journal of Science Frontier Research Environment and Earth Sciences, 12(3), 1-11.

Bagozzi, R. P., and Yi, Y. (2012). Specification, evaluation and interpretation of structural equation models. Journal of the Academy of Marketing Science. Doi: 10.1007/s11747-011-0278-x

Becker, G. S. (1993). Human Capital: A Theoretical and Empirical Analysis with Special Reference to Education (3rd ed.). University of Chicago Press, Chicago

Berger, R., Romeo, M., Guardia, J., Yepes, M. and Soria, M. A. (2012). Psychometric properties of the Spanish human system audit short-scale of transformational leadership. The Spanish Journal of Psychology, 15(1), 367-376. Retrieved from http://www.academia.edu/11528197/Psychometric Properties of the Spanish Human System Audi $\mathrm{t}$ Short-Scale of Transformational Leadership

Boone, H. N., and Boone, D. A. (2012). Analyzing Likert data. Journal of Extension, 50(2). Retrieved from https://www.joe.org/joe/2012april/pdf/JOE v50 2tt2.pdf

Boyd, J. H., and De Nidolo, G. (2005). The theory of bank risk-takingg and competition revisited. Journal of Finance, 60(3), 1329-1343. Doi: https://doi.org/10.1111/j.1540-6261.2005.00763.x

Cella-De-Oliveira, F. A. (2013). Indicators of organizational sustainability: A proposition from organizational competences. International Review of Management and Business Research, 2, 962-979. Retrieved from http://www.irmbrjournal.com/papers/1384877991.pdf

Cressy, R. (2006). Why do Most Firms Die Young? Small Business Economics, 26(2), 103-116.

Cusack, J. L. (2007). Metrics for measuring sustainability performance - Latest developments in the financial and higher education sectors. 2007 TBLI Conference. Retrieved from https://www.slideshare.net/tbliconference/metrics-for-measuring-sustainability-performance-latestdevelopments-in-the-financial-and-higher-education-sectors

De Jong, J., and Wennekers, S. (2008). Intrapreneurship - Conceptualizing entrepreneurial employee behaviour. Scientific Analysis of Entrepreneurship and SMEs. Retrieved from http://ondernemerschap.panteia.nl/pdf-ez/h200802.pdf

De Jong, J., Parker, S. A., Wennekers, S. and Wu, C. (2011). Corporate entrepreneurship at the individual level Measurement and determinants. Scientific Analysis of Entrepreneurship and SMEs. Retrieved from http://ondernemerschap.panteia.nl/pdf-ez/h201108.pdf

DPR (2015). Department of petroleum resources 2015 oil and gas annual report. Retrieved from https:/dpr.gov.ng/index/wp-content/uploads/2015/01/2015-Oil-Gas-Industry-Annual-Report.pdf

Egwuonwu, J. A. (2014). Corporate Social Responsibility and Environmental Sustainability in the Niger Delta: A case study of Chevron Nigeria Limited. MSc Dissertation Summited to York University Toronto, Ontario, Canada.

Frynas, J. G. (2005). The false development promise of corporate social responsibility: Evidence from multinational oil companies. International Affairs, 81, 581-598.

Hair, J. F., Black, W. C., Babin, B. J., and Anderson, R. E. (2010). Multivariate Data Analysis: A Global Perspective (7th ed.). New Jersey, Pearson Education International.

Hornaday, J. A., Tarpley Jr., F. and Timmons, J. A. (1984). Frontiers of entrepreneurship research. Wellesley, MA: Babson College, 294-326.

Idemudia, U. (2007). Community perceptions and expectations: reinventing the wheels of corporate social responsibility practices in the Nigerian oil industry. Business and Society Review, 112,(3), 369-405.

Jaquier, B. (2010). The resource-based view of the firm. Retrieved from http://www.ecofine.com/strategy/RBV\%20of $\% 20$ the $\% 20$ firm.html

Joshi, A., Kale, S., Chandel, S. and Pal, D. K. (2015). Likert scale: Explored and explained. British Journal of Applied Science and Technology, 7(4), 396-403. Doi: 10.9734/BJAST/2015/14975

Kimeu, D. N. (2017). The effect of entrepreneurial competencies on business performance: A case of Kenya's public transport industry. MBA Dissertation Submitted to the Chandaria School of Business.

Ling, Y., Simsek, Z., Lubatkin, M. H. and Veiga, J. F. (2008). Transformational leadership's role in promoting corporate entrepreneurship: Examining the CEO-TMT interface. Academy of Management Journal, 51(3), 557-576.

Lumpkin, G. G. and Dess, G. T. (2005). The role of entrepreneurial orientation in stimulating effective corporate entrepreneurship. Academy of Management Executive, 19(1), 147-156.

Maletič, M., Maletič, D., \& Gomišček, B. (2012). An organizational sustainability performance measurement framework. Recent Researches in Environment, Energy Systems and Sustainability, 220-225. Retrieved from http:/www.wseas.us/e-library/conferences/2012/Algarve/EEESD/EEESD-34.pdf 
Marimuthu, M., Arokiasamy, L., and Ismail, M. (2009). Human capital development and its impacts on firm performance: Evidence from Development Economics. The Journal of International Social Research, 44(1), 265-272.

Mirta, D. F., Alvaro, L. C. and Ramon, V. C. (2014). A contingent approach to the role of human capital and competencies on firm strategy. Business Research Quarterly, 17(3), 205-222. Doi: https://doi.org/10.1016/j.brq.2014.01.002

Ndubuisi, O. L., and Asia, I. O. (2007). Environmental pollution in oil producing areas of the Niger Delta Basin, Nigeria: Empirical assessment of trends and people's perception. Environmental Resources Journal, $1,18-26$.

Nieuwenhuizen, C. and Kroon, J. (2002). Identification of entrepreneurial success factors to determine the content of entrepreneurship subjects. South African Journal of Higher Education, 16(3), 157-166.

Norman, G. (2010). Likert scales, levels of measurement and the "laws" of statistics. Advance in Health Science Education. DOI 10.1007/s10459-010-9222-y

Nunnally, J. C. (1979). Psychometric theory. New York, McGraw Hill.

Nunnally, J. C. (1978). Psychometric theory (2 ${ }^{\text {nd }}$. ed). New York: McGraw Hill. Retrieved from www.core.ecu.edu/psyc/wuenschk/StatHelp/Reliab-Nunnally.docx

Odlhon'g, E. A. and Omolo, J. (2015). Effect of human capital development on organizational performance of pharmaceutical companies in Kenya. Global Journal of Human Resource Management 3(6), 1-9. Retrieved from: www.eajournals.org

Onishi, N. (2002). As oil riches flow, poor village cries out. New York Times, 22 December. Retrieved $3^{\text {rd }}$ September 2004 from: www.earthrights.net/nigeria/news/richesflow.html

Otiotio, D. (2016). An overview of the oil and gas industry in Nigeria. Retrieved from https://www.academia.edu/2654835/an overview of the oil and gas industry in nigeria by denni s otiotio

Parker, S. K. and Collins, C. G. (2010). Taking stock: Integrating and differentiating multiple proactive behaviours. Journal of Management, 36, 633-662. doi: 10.1177/0149206308321554

Pinchot, G. (1987). Innovation through Intrapreneuring. Research Management, 30(2), 14-19.

Porter, M. E., and Kramer, M. R. (2011). Creating shared value: How to reinvent capitalism and unleash a wave of innovation and growth. Harvard Business Review, 89(1), 1-17. Retrieved from http://www.hks.harvard.edu/

Rauch, A., and Frese, M. (2007). Let's put the person back into entrepreneurship research: A meta-analysis of the relationship between business owners' personality characteristics and business creation and success. European Journal of Work and Organizational Psychology, 16(4), 353- 385.

Rauch, A., Wiklund, J., Lumpkin, G. T. and Frese, M. (2009, May). Entrepreneurial orientation and business performance: An assessment of past research and suggestions for the future. Entrepreneurship Theory \& Practice, 761-787.

Schultz, T. W. (1993). The economic importance of human capital in modernization. Education Economics, 1(1), 13-19.

Sekaran, U. (2008). Research methods for business. New York: John Wesley and Sons.

Severine, D. and Lila, S. (2009). An Introduction to the Human Development and Capability Approach, Freedom and Agency. Earth Scan, London.

Statistics Solutions (2017). Assumptions of multiple linear regression. Retrieved from http:/www.statisticssolutions.com/assumptions-of-multiple-linear-regression/.

Takon, N. (2014). Environmental damage arising from oil operations in Niger Delta of Nigeria: How not to continually live with their specific impact on population and ecology. International Journal of Development and Sustainability, 3(9), 1878-189. Retrieved from: www.isdsnet.com/ijds

Uguchukwu, C. N. C. (2008). Sustainable environmental management in the Niger Delta Region of Nigeria: effects of hydrocarbon pollution on local economy. A Phd Thesis Summited to Brandenburg University of Technology, Cottbus. Retrieved from: https://www.researchgate.net/publication/283376351

Veliu, L. and Manxhari, M. (2017). The impact of managerial competencies on business performance: SME's in Kosovo. Vadyba Journal of Management, 1(30), 59-65.

Wales, T. (2013). Organizational sustainability: What is it, and why does it matter?. Review of Enterprise and Management Studies, 1(1), 38-49. Retrieved from https://www.uos.ac.uk/sites/default/files/basic_file/REAMS_1-(1)_Wales-v2.pdf

Weli, U. (2017, August 16). Imperatives for development in the Niger Delta region of Nigeria. Canvas for Niger Delta, Nigeria Info. Port Harcourt, Nigeria: Aim Communications 
Wennekers, S., Thurik, R., van Stel, A. and Noorderhaven, N. (2007). Uncertainty avoidance and the rate of business ownership across 21 OECD countries, 1976-2004. Journal of Evolutionary Economics, 17, 133-160.

Williams, R. (2015). Heteroscedasticity. Retrieved from https://www3.nd.edu/ rwilliam/stats2/125.pdf

Worley, J. A., Fuqua, D. R. and Hellman, C. M. (2009). The survey of perceived organisational support: Which measure should we use? South Africa Journal of Industrial Psychology, 35(1). Retrieved from https://www.researchgate.net/publication/47740048 The Survey of Perceived_Organizational_Supp ort Which Measure Should We Use 